\title{
Total factor productivity change in dairy farming: Empirical evidence from southern Chile
}

\author{
Víctor H. Moreira*1 and Boris E. Bravo-Ureta†‡ \\ *Instituto de Economía Agraria, Universidad Austral de Chile, Valdivia 5090000, Chile \\ †Agricultural and Resource Economics Department, University of Connecticut, Storrs 06269 \\ ‡Departamento de Economía Agraria, Universidad de Talca, Talca 3460000, Chile
}

\section{ABSTRACT}

Despite the importance of productivity growth, many studies carried out at the farm level focus primarily on the technical efficiency (TE) component of farm productivity. Therefore, the general purpose of this paper is to measure total factor productivity change and then to decompose this change into several distinct elements. The data were an unbalanced panel for the period from 2005 to 2010 containing 477 farms and 1,426 observations obtained from TODOAGRO, a farm-management center created in 1996 in the southern part of Chile. The region where the data come from accounts for $20 \%$ of the total milk processed in the country. Stochastic production frontiers along with the translog functional form were used to analyze total factor productivity change. The econometric evidence indicates that farms exhibit decreasing returns to size implying that costs of production rise as farm size increases, which suggests that the motivation for farm growth stems from the search for income rather than from lowering costs. The main results indicated that productivity gains through TE improvements are limited, with an average TE for the whole sample of $91.0 \%$, and average technical efficiency change of $0.05 \%$ per year. By contrast, average technological progress at the sample mean was rather high at $1.90 \%$, which suggests that additional investments in research and subsequent adoption of improved technologies would have a positive effect on productivity growth. The findings also revealed that farm size is not associated with productivity growth for the dairy farms in the sample.

Key words: dairy farm productivity, stochastic production frontier, Chile

Received February 19, 2016.

Accepted June 12, 2016.

${ }^{1}$ Corresponding author: vmoreira@uach.cl

\section{INTRODUCTION}

The measurement and analysis of productivity has attracted the attention of economists for a long time, and has resurfaced as a topic of interest particularly in the context of poverty alleviation within the Millennium Development Agenda (Hazell et al., 2007) and more recently the Sustainable Development Goals (United Nations, 2015). Moreover, for developing countries facing an increasingly globalized economic environment, productivity growth and improving competitiveness is essential to ensure the prosperity of agriculture and contribute to poverty reduction (Thirtle et al., 2003; World Bank, 2003, 2008).

Analysis of productivity growth over time and productivity differentials between countries, regions, and farms have been and remain important subjects of formal analysis in agricultural and development economics (Berry and Cline, 1979; Carletto et al., 2013). Furthermore, rapid rates of income and population growth are expected to double the demand for agricultural products over the next 50 yr. Hence, substantial gains in farm productivity are needed to keep up with this expanding demand (Ruttan, 2002; Rao and Coelli, 2004; Chen et al., 2008; Fuglie, 2010).

Researchers have spent much effort examining managerial performance in agriculture, which is often proxied by technical efficiency (TE), and a considerable share of this work has focused on dairy farming. However, as documented by Bravo-Ureta et al. (2007) and Moreira and Bravo-Ureta (2009), only a limited number of these farm level studies have gone beyond the TE component of productivity. Exceptions where a more comprehensive analysis of production and productivity growth is undertaken include works by Lachaal (1994), Ahmad and Bravo-Ureta (1995; 1996), Tauer (1998), Mosheim and Lovell (2009), and Qi et al. (2015) for the United States; Richards (1995) for Canada; Piesse et al. (1996) for the former Yugoslavia; Brümmer et al. (2002) for 3 European countries; Newman and Matthews (2007) for Ireland; and Kumbhakar et al. (2008) for Norway. It 
is important to note the recent article by Kellermann and Salhofer (2014), who conducted a total factor productivity (TFP) analysis of dairy farms in Bavaria Germany and examined whether grassland dairy farms are able to keep up with their fodder-crop counterparts in terms of productive performance.

As noted above, most efficiency studies including those dealing with dairy farming are focused on TE. The inclusion of allocative efficiency (AE) in productivity growth analyses is limited and we find it useful to provide an overview of some AE dairy efficiency studies.

The first published study to examine $\mathrm{AE}$ in dairy production, along with technical and scale efficiencies within a frontier framework, was by Bailey et al. (1989). Those authors, using cross-sectional data for a sample of 68 Ecuadorian dairy farms in 1986, found that technical inefficiency ranged from 11.8 to $12.8 \%$ and that large- and medium-sized farms exhibited higher AE than small farms. However, most farms in the sample were producing below the optimum level of output. Dawson and White (1990) used stochastic production frontiers and data from 3 yr (1984-1985 and 1986-1987) for 306 dairy farms from England and Wales to analyze AE and TE after dairy production quotas were introduced in April 1984. The key results are that producers were able to adjust the $\mathrm{AE}$ of variable inputs whereas TE remained fairly constant over the period of analysis.

Bravo-Ureta and Rieger (1991) extended the deterministic Kopp and Diewert (1982) framework to a stochastic production frontier model and, invoking the self-duality of the Cobb-Douglas technology, examined TE, AE, and economic efficiency (EE) for a cross-sectional sample of 511 New England dairy farms from 1984. The authors reported an average level of EE equal to $70 \%$, whereas average $\mathrm{TE}$ and $\mathrm{AE}$ were very similar at 83 and $85 \%$, respectively. No clear association between efficiency, farm size, education, extension, and experience was found.

Kumbhakar et al. (1991) developed a generalized production frontier model to measure $\mathrm{TE}$ and $\mathrm{AE}$ for a cross-sectional sample of US dairy farms from 1985. Their results revealed that education is positively associated with TE and that larger farms are relatively more profitable than smaller ones while exhibiting higher TE and AE.

Tauer (1993) used data envelopment analysis (DEA) to investigate short- and long-run $\mathrm{TE}$ and $\mathrm{AE}$ for 395 New York dairy farms using data from 1990. The analysis revealed that, on average, $\mathrm{AE}$ was higher in the short run than in the long run, but the opposite was true for TE. In another DEA study, Hansson and Öhlmér (2008) examined the connection between operational practices and efficiency using unbalanced panel data for Swedish dairy farms. The results showed that managerial practices can have differential effects on long-run TE, long-run AE, as well as on short-run EE. Finally, Maietta (2000) used a shadow cost model to obtain $\mathrm{EE}, \mathrm{AE}$, and $\mathrm{TE}$ using a panel data set for Italian dairy farms and reported that costs are, on average, $69 \%$ higher than what they should be primarily as a result of technical inefficiency.

In summary, several studies have examined different aspects of productivity in dairy farms using a variety of methodologies and data sets. However, the bulk of the work has focused on TE whereas limited efforts have been reported where total factor productivity change (TFPC) is measured and then fully decomposed using farm-level data. We studied this matter for a large sample of Chilean dairy farms to glean possible implications for the future structure of this important agricultural sector.

The general purpose of our paper was to measure and examine TFPC based on high-quality data from a sample of Chilean dairy operations. Our hypothesis was that the relative importance of the various components of TFP changes over time, and at that a connection exists between farm size and TFP. The specific objective of our study was to decompose TFPC and then to examine the connection between the various components.

\section{MATERIALS AND METHODS}

In Chile, several farm-management centers (FMC) are working with different types of farmers. The main activity of an FMC is to collect farm-level technical and economic information. These data are then used for benchmarking farms and to analyze the main factors associated with best and worst economic performance (Fundación Chile, 2007). TODOAGRO, created in 1996, was for several years the largest FMC operating in the southern part of the country, a region that accounts for $20 \%$ of the total milk processed in Chile.

The TODOAGRO data used in this study are from an unbalanced panel including 477 dairy farms located mainly in the Los Lagos and Los Ríos regions in southern Chile. The data are annual figures covering the years 2005 to 2010 with a total of 1,426 observations (Table 1). Most of the farms in the data set have information for more than $1 \mathrm{yr}$. More specifically, almost $15 \%$ of the farms have data for all 6 yr (432 observations); $11 \%$ of the farms have data for 5 yr (260 observations); $8 \%$ have data for $4 \mathrm{yr}$ (160 observations); $17 \%$ for $3 \mathrm{yr}$ (240 observations); $21 \%$ for 2 yr (203 observations); and the rest of the farms have data for only 1 yr (131 observations). 
Table 1 presents the distribution of farms per year as well as the mean for all variables included in the production frontier model along with other key indicators of farm performance. Overall, the data in Table 1 reveal noticeable differences across variables. The number of farms fluctuates between 284 in 2006 and 195 in 2005. Average milk production per farm was 1,652,962 L over the 2005 to 2010 period, whereas average herd size was 264 cows. Although not shown in Table 1, the smallest farm in the sample had 18 cows in 2006 and the largest had 1,738 in 2010, but most of the figures are close to the average reported in Table 1 . Therefore, the sample included significant variability in terms of herd size.

The average number of hectares devoted to the dairy enterprise was 139. Again, although not shown in Table 1 , total hectares per farm exhibited significant variation going from a minimum of 5 in 2006 to a maximum of 798 in 2005. Table 1 shows an upward trend in average milk production per cow, except for 2009, whereas feed concentrate per cow exhibits a similar tendency (bottom of Table 1).

As indicated, the purpose of this paper is to measure and decompose TFPC and then to examine the various components of productivity change. To address this, we followed the methodological approach presented by Kumbhakar and Lovell (2000). We started by assuming that panel data are available, and then we wrote the following stochastic production frontier (SPF) model:

$$
y_{i t}=\exp \left(x_{i t} \boldsymbol{\beta}+v_{i t}-u_{i t}\right),
$$

where $y_{i t}$ denotes output for the $i$ th farm in the th time period; $x_{i t}$ is a vector of inputs and other explanatory variables (e.g., time) for the $i$ th farm in the th time period; $\boldsymbol{\beta}$ is a vector of unknown parameters to be estimated; $v_{i t}$ is a random error assumed to follow a normal distribution with mean zero and constant variance $\left[v_{i} \sim i i d N\left(0, \sigma_{v}^{2}\right)\right]$, where iid is independent, identically distributed random variables, $N$ is normal distribution, and $\sigma$ is variance; and $u_{i t}$ is a nonnegative unobservable random error which captures the technical inefficiency of the $i$ th farm in period $t$. Thus, TE is modeled as time variant which is a desirable choice when decomposing productivity growth (Coelli et al., 2003).

The inefficiency effects, $u_{i t}$, in the stochastic frontier model (equation 1) can be expressed as:

$$
u_{i t}=\boldsymbol{z}_{i t} \boldsymbol{\delta}+w_{i t},
$$

where $w_{i t}$ is a random variable defined by the truncation of the normal distribution with zero mean and variance $\sigma^{2}, \boldsymbol{z}_{i t}$ is a vector of variables which may influence the efficiency of a farm, and $\boldsymbol{\delta}$ is a vector of parameters to be estimated.

The TE for the $i$ th farm in period $t$ is equal to $\exp (-$ $\left.u_{i t}\right)$. The term $u_{i t}$ cannot be measured directly, but it is part of the composed error term. However, the conditional expectation of $\exp \left(-u_{i t}\right)$ can be derived from the composed error term of the stochastic model following Jondrow et al. (1982) and Battese and Coelli (1988). For the analysis reported below, all parameters of the SPF model are estimated using the program Frontier 4.1, developed by Coelli (1996). The Frontier software provides maximum likelihood estimates for all the parameters of the production frontier, and the model can accommodate balanced and unbalanced panel data (Coelli, 1996).

Table 1. Descriptive statistics for the dairy farms in the sample: 2005-2010

\begin{tabular}{lrrrrrr}
\hline & \multicolumn{7}{c}{ Years } \\
\cline { 2 - 7 } Variables & 2005 & 2006 & 2007 & 2008 & 2009 & 2010 \\
\hline Number of farms & 195 & 284 & 259 & 245 & 237 & 206 \\
Production function variables average/farm & & & & & & \\
$\quad$ Milk production (per 1,000 L) & 1,674 & 1,479 & 1,570 & 1,654 & 1,657 & 1,969 \\
Herd size (dairy cows) & 270 & 236 & 251 & 261 & 277 & 299 \\
Concentrate feed (t) & 416 & 347 & 378 & 417 & 378 & 410 \\
Forage expenses (MM Ch\$1) & 36 & 29 & 42 & 62 & 51 & 52 \\
Labor expenses (MM Ch\$) & 32 & 28 & 30 & 34 & 34 & 38 \\
Veterinary expenses (MM Ch\$) & 12 & 10 & 13 & 14 & 14 & 15 \\
Other expenses (MM Ch\$) & 45 & 37 & 41 & 49 & 47 & 51 \\
Other variables & 141 & 125 & 129 & 137 & 147 & 161 \\
$\quad$ Land (ha) & 1,358 & 1,246 & 1,318 & 1,422 & 1,173 & 1,208 \\
Concentrate feed (kg/cow) & 5,350 & 5,401 & 5,499 & 5,626 & 5,166 & 5,679 \\
Milk production (L/cow) & & & & & &
\end{tabular}




\section{TFPC Decomposition}

As defined in the literature, output growth is the combination of productivity growth and the growth in inputs or the size effect. Productivity growth is commonly defined as the part of output growth that cannot be explained by the growth in inputs under the assumption that farms are producing on the frontier (Ahmad and Bravo-Ureta, 1995). If inefficiency is ignored, productivity growth is synonymous with technological change (Morrison, 1999). Nishimizu and Page (1982) were the first to decompose productivity growth into technological progress (TP) and technical efficiency change (TEC), use production frontiers, and also incorporate the input or size effect. More recently, Kumbhakar and Lovell (2000), following Bauer (1990), extended the decomposition of TFPC in primal stochastic frontiers by incorporating scale efficiency change (SEC) and allocative efficiency change (AEC).

The TP represents a jump or an upward shift in the production frontier and has received a great deal of attention in the literature for many years following publication by Solow (1957). By comparison, TEC is associated with improvements in performance which are linked with managerial effort (Martin and Page, 1983). It is important to note that a farm could increase its productivity even if there is no TP by making a more efficient use of its inputs (i.e., by operating closer to its production frontier). The SEC measures the contribution of scale economies to productivity change, whereas AEC captures the farm's ability to adjust the mix of inputs so that input price ratios are equal to the ratios of corresponding marginal products (Coelli et al., 2003).

The first step to address in quantifying TFPC using SPF is the choice of a functional form. Empirical research frequently relies on the relatively simple CobbDouglas (CD) functional form. However, given the restrictive nature of the $\mathrm{CD}$, a more flexible alternative is the translog (TL), also commonly used in productivity studies (Bravo-Ureta et al., 2007). We use a TL production function that can be written as

$$
\begin{gathered}
y_{i t}=\alpha_{0}+\sum_{k=1}^{K} \beta_{k} x_{k i t}+\frac{1}{2} \sum_{k=1}^{K} \sum_{l=1}^{K} \beta_{k l} x_{k i t} \times x_{l i t}+ \\
\sum_{i=1}^{n} \delta_{k} x_{k i t} \times T+\lambda_{1} T+\frac{1}{2} \lambda_{11} T^{2}+v_{i t}-u_{i t},
\end{gathered}
$$

where the subscripts kit refer to the $k$ th input, the $i$ th farm, and the th time period. Dairy is the main activity of TODOAGRO members who also produce other outputs primarily small grains, beef, potatoes, and blueberries. In this study, the available data were only related to milk and milk by-products; thus, the dependent variable $(y)$ is expressed in total liters of milk equivalent per year per farm, calculated as the sum of milk sales plus dairy livestock sales divided by the average milk price received by each farm in each year. The data are calculated and reported by TODOAGRO and are similar to what has been used in other dairy studies (e.g., Reinhard et al., 1999, and Qi et al., 2015).

We used 6 inputs, all expressed in natural logarithms and as annual flows per farm. The model specification is consistent with other dairy papers such as Reinhard et al. (1999), Lawson et al. (2004a,b), and Cabrera et al. (2010), among others. The regressors incorporated are defined as follows: $\mathrm{CO}=$ total dairy cows; $\mathrm{CF}=$ concentrate feed (metric tonnes); LB = labor equal to total wages paid to hired workers plus family labor valued using the legally minimum wage [Chilean pesos $(\mathbf{C h} \$)] ; \mathrm{FE}=$ forage feed expenses including the cost of forage produced on farm $(\mathrm{Ch} \$)$; VE = veterinary expenses including insemination and veterinary supplies $(\mathrm{Ch} \$)$; and $\mathrm{OE}=$ other expenses corresponding to the dairy enterprise including power, fuel, and depreciation of machinery and buildings (Ch\$; Fundación Chile, 2007). All monetary terms are deflated and expressed in real Chilean pesos $(\mathrm{Ch} \$)$ using the Chilean consumer price index with December 2012 as the base period.

In addition, the dummy variable (DD) is introduced to capture the effect of an unusual drought over the period 2007 to 2010 (DD = 1), which had significant consequences in the region under analysis because farmers do not use irrigation and rely heavily on permanent pastures. The variable $\mathrm{T}$ is a smooth time trend that captures $\mathrm{TP}(\mathrm{T}=1,2,3,4,5$, and 6 for 2005, 2006, 2007, 2008, 2009, and 2010, respectively); $v_{i t}$ is the standard normally distributed random error; $u_{i t}$ is a one side error term that captures inefficiency; and the Greek letters represent parameters to be estimated. The data expressed in monetary terms ( $\mathrm{LB}$ and FE) implies that input prices are assumed constant across farmers on a given year, which is reasonable given the relative close proximity of the producers in the sample; thus, the variable expenses can be interpreted as implicit quantities. In addition, we included farm size in the inefficiency component of the model as follows: LD $=$ land in hectares; and $\mathrm{LD}^{2}=$ land squared. It would also be informative to include variables related to human capital in the latter part for the model; however, the database available does not contain such variables.

The natural logarithm of TFPC between 2 consecutive periods (denoted by $t=0$ and $t=1$ in equation 4 ) for the ith farm, given a TL functional form (equation 3), can be expressed as (Coelli et al., 2003): 


$$
\begin{aligned}
& \ln \left(\frac{\mathrm{TFP}_{i 1}}{\mathrm{TFP}_{i 0}}\right)=\underbrace{\ln \left(\frac{\mathrm{TE}_{i 1}}{\mathrm{TE}_{i 0}}\right)}_{\mathrm{TEC}}+\underbrace{\frac{1}{2}\left[\left(\frac{\partial \ln y_{i 0}}{\partial t}\right)+\left(\frac{\partial \ln y_{i 1}}{\partial t}\right)\right]}_{\mathrm{TP}}+ \\
& \underbrace{\frac{1}{2} \sum_{k=1}^{K}\left[\left(\mathrm{SF}_{i 0} \times e_{k i 0}+\mathrm{SF}_{i 1} \times e_{k i 1}\right) \times\left(\ln x_{k i 1}-\ln x_{k i 0}\right)\right]}_{\mathrm{SEC}}+[4] \\
& \underbrace{\frac{1}{2} \sum_{k=1}^{K}\left\langle\left[\left(\frac{e_{k i 1}}{e_{i 1}}-s_{k i 1}\right)+\left(\frac{e_{k i 0}}{e_{i 0}}-s_{k i 0}\right)\right] \times\left(x_{k i 1}-x_{k i 0}\right)\right\rangle}_{\mathrm{AEC}},
\end{aligned}
$$

where $\mathrm{TE}_{i t}$ is the predicted $\mathrm{TE}$ for the $i$ th farm in time period $t$, as previously explained; $\mathrm{TP}_{i 0}$ is the average of the partial derivatives of output $(y)$ with respect to $t$ $\left(\frac{\partial \ln y_{i 0}}{\partial t}\right)$ for a given farm for 2 consecutive periods; and $s_{k i t}$ is the cost share of the $k$ th input of the $i$ th farm in time period $t$, which is needed to calculate AEC. The calculation of SEC requires values for the partial elasticities of production $\left(e_{i t}\right)$, and also the scale factor (SF) to be computed at each data point, where $e_{i t}=\sum_{k=1}^{K} e_{k i t}$ and $\mathrm{SF}_{i t}=\frac{\left(e_{i t}-1\right)}{e_{i t}}$. Under constant returns to scale, $e_{i t}$ is equal to 1 , and hence the scale term in equation 4 is equal to 0 .

\section{RESULTS AND DISCUSSION}

The econometric results revealed that of the 36 parameters estimated for the production frontier, excluding the intercept, 13 are significant at the $1 \%$ level including all 6 linear parameters for the inputs; one is significant at 5\%, 5 at $10 \%$, and 17 are not significant at conventional levels (Table 2). We normalized all variables by their respective geometric means before estimation; thus, the linear parameters for the inputs represent partial elasticities of production (Coelli et al., 2003). We should also highlight the fact that the gamma parameter is equal to 0.950 and significant at the $1 \%$ level, indicating that an important share of the variability in output is due to technical inefficiency.

The TL has the advantage of being a flexible functional form, but its disadvantage is that regularity conditions stemming from economic theory are not globally satisfied and violations are often present. Hence, this is an issue that needs to be verified ideally at each data point. The most important regularity condition is monotonicity, which implies that any additional units of an input will not decrease output. This condition requires that the partial elasticities of production, defined as the percentage change in output associated with a one percent change on a given input, must be positive at all points in the data and for all inputs (Coelli et al., 2005). The model estimated here (Table 2) was well-behaved, exhibiting a very low number of violations. A preliminary analysis of the data revealed that the number of cows $(\mathrm{CO})$ is particularly well-behaved, with only 2 violations of monotonicity (out of 1,426). The largest number of violations was for concentrate feed $(\mathrm{CF})$ with 32 , which represented only $2.2 \%$ of the total observations. The data points that did not fulfil monotonicity were dropped in the subsequent analysis; thus, the number of observations was reduced to 1,367 (59 were dropped, $4.1 \%$ of the total).

As is often the case in dairy studies (e.g., Cabrera et al., 2010; del Corral et al., 2011; van der Voort et al., 2014), the partial elasticity of production with the highest value was for $\mathrm{CO}$, ranging from 0.374 for the largest quintile to 0.362 for the second quintile, with an overall average of 0.367 ; in other words, for the entire sample, a $10 \%$ increase in the number of cows would lead to a $3.67 \%$ rise in milk production. The quintiles are defined in terms of the volume of milk production.

The second most important input was concentrate feed $(\mathrm{CF})$, with an overall average partial elasticity of 0.217 , which is also consistent with previous studies. The parameter for the DD variable was highly significant and negative, which is consistent with the prior expectation that a severe drought in a nonirrigated pasture-dependent system would have an adverse effect on dairy output. We note that the model specification that included DD performed better, on statistical grounds, than a restricted alternative that excluded this variable.

The sum of the partial elasticities of production, known as the function coefficient, provides a measure of returns to scale (RTS). The data in Table 2 show that the average value of the function coefficient was 0.940 and calculations reveal that these values were remarkably close across the 5 quintiles ranging from 0.915 for quintile I to 0.959 for quintile $\mathrm{V}$. Keeping in mind that constant returns to size prevail when the value of the function coefficient is 1.0, we can conclude that this sample exhibited decreasing returns to scale (DRS), and this is significant at the $1 \%$ level when the one sample mean comparison test is applied (Acock, 2010). The DRS means that as all inputs increase by a certain percentage, output expands more slowly. Hence, an important implication of DRS is that per-unit production costs increase as inputs expand faster than output (Coelli et al., 2005).

The inefficiency component of the model (Table 2) showed that LD had a positive and significant influ- 
ence on TE, which means that as farm size increases $\mathrm{TE}$ also increases but at a decreasing rate because the parameter for $\mathrm{LD}^{2}$ is positive and significant.

The component of productivity that has received most attention in the empirical literature focusing on dairy farming is TE (Bravo-Ureta et al., 2007; Moreira and Bravo-Ureta, 2009). Table 3 contains descriptive statistics for TE scores by quintile according to the volume of milk production. As the data show, average TE scores across quintiles were similar. These scores ranged from $85.3 \%$ for quintile I to $94.6 \%$ for quintile $\mathrm{V}$, showing a slight positive association with farm output, similar to those recently published by Bojnec and Latruffe (2013). Taking into account the extreme points, it can be observed that the lowest level of TE was $32.0 \%$ for a farm in quintile I, and the highest was $99.8 \%$ for a farm in quintile II. The overall mean for the entire sample was $91.1 \%$, which is several points higher than the $83.3 \%$ calculated from 32 dairy farm studies that used stochastic frontiers as reported by Moreira and Bravo-Ureta (2009) in their dairy meta-analysis.

The last part of the analysis focused on the decomposition of TFPC based on equation (3). We calculated 2 measures of TFPC: (1) TFPC1, which included TEC,

Table 2. Parameter estimates for the translog production frontier model

\begin{tabular}{|c|c|c|}
\hline Variable $^{1}$ & Parameter & $\mathrm{SE}$ \\
\hline \multicolumn{3}{|l|}{ Frontier model } \\
\hline Constant & $0.105^{* * *}$ & 0.018 \\
\hline $\mathrm{CO}$ & $0.374^{* * *}$ & 0.016 \\
\hline $\mathrm{CF}$ & $0.210^{* * *}$ & 0.008 \\
\hline $\mathrm{LB}$ & $0.069^{* * *}$ & 0.013 \\
\hline $\mathrm{FE}$ & $0.099^{* * *}$ & 0.010 \\
\hline VE & $0.089^{* * *}$ & 0.012 \\
\hline $\mathrm{OE}$ & $0.099^{* * *}$ & 0.014 \\
\hline $\mathrm{T}$ & $0.019^{* * *}$ & 0.005 \\
\hline DD & $-0.103^{* * *}$ & 0.019 \\
\hline $\mathrm{CO}^{2}$ & 0.026 & 0.072 \\
\hline $\mathrm{CF}^{2}$ & $0.056^{* * *}$ & 0.004 \\
\hline $\mathrm{LB}^{2}$ & $0.077^{*}$ & 0.045 \\
\hline $\mathrm{FE}^{2}$ & 0.020 & 0.023 \\
\hline $\mathrm{VE}^{2}$ & $0.016^{* * *}$ & 0.004 \\
\hline $\mathrm{OE}^{2}$ & $0.009^{* * *}$ & 0.003 \\
\hline $\mathrm{T}^{2}$ & $0.010^{* *}$ & 0.004 \\
\hline $\mathrm{CO} \mathrm{CF}$ & $-0.082^{* * *}$ & 0.016 \\
\hline CO LB & -0.039 & 0.042 \\
\hline $\mathrm{CO} \mathrm{FE}$ & 0.036 & 0.031 \\
\hline CO VE & 0.021 & 0.036 \\
\hline $\mathrm{CO} \mathrm{OE}$ & $0.075^{*}$ & 0.040 \\
\hline $\mathrm{CO} \mathrm{T}$ & $-0.034^{* * *}$ & 0.010 \\
\hline CF LB & -0.012 & 0.015 \\
\hline CF FE & 0.008 & 0.009 \\
\hline CF VE & $0.018^{*}$ & 0.009 \\
\hline $\mathrm{CF} \mathrm{OE}$ & -0.012 & 0.013 \\
\hline $\mathrm{CF} \mathrm{T}$ & 0.002 & 0.003 \\
\hline LB FE & -0.008 & 0.025 \\
\hline LB VE & -0.025 & 0.028 \\
\hline LB OE & 0.001 & 0.024 \\
\hline $\mathrm{LB} \mathrm{T}$ & $0.014^{*}$ & 0.008 \\
\hline FE VE & -0.017 & 0.021 \\
\hline FE OE & $-0.045^{*}$ & 0.025 \\
\hline FE T & -0.004 & 0.006 \\
\hline $\mathrm{VE} \mathrm{OE}$ & -0.005 & 0.032 \\
\hline VE T & 0.004 & 0.006 \\
\hline $\mathrm{OE} \mathrm{T}$ & 0.012 & 0.008 \\
\hline \multicolumn{3}{|l|}{ Inefficiency component } \\
\hline Constant & $-0.491^{* * *}$ & 0.142 \\
\hline LD & $-1.595^{* * *}$ & 0.298 \\
\hline $\mathrm{LD}^{2}$ & $0.192^{* * *}$ & 0.036 \\
\hline Sigma-squared & $0.227^{* * *}$ & 0.037 \\
\hline Gamma & $0.950^{* * *}$ & 0.007 \\
\hline Function coefficient (at the geometric mean) & 0.940 & \\
\hline Log-likelihood Function & 736.2 & \\
\hline Number of observations & 1,426 & \\
\hline
\end{tabular}

${ }^{1} \mathrm{CO}=$ cows; $\mathrm{CF}=$ concentrate feed $\mathrm{LB}=$ labor; $\mathrm{FE}=$ forage expenses; $\mathrm{VE}=$ veterinary expenses; $\mathrm{OE}=$ other expenses: $\mathrm{T}=$ time; $\mathrm{DD}=$ drought dummy; $\mathrm{LD}=$ land size. 
Table 3. Technical efficiency (TE) scores by quintiles in terms of milk production and overall

\begin{tabular}{|c|c|c|c|c|c|c|}
\hline \multirow[b]{2}{*}{ Groups $^{1}$} & & \multirow[b]{2}{*}{ No. of farms } & \multirow[b]{2}{*}{ Milk equivalent (L) } & \multicolumn{3}{|c|}{$\mathrm{TE}$} \\
\hline & & & & Mean & Minimum & Maximum \\
\hline $0-20 \%$ & I & 258 & 356,273 & 0.853 & 0.320 & 0.972 \\
\hline $20-40 \%$ & II & 275 & 811,290 & 0.896 & 0.506 & 0.998 \\
\hline $40-60 \%$ & III & 277 & $1,345,129$ & 0.923 & 0.670 & 0.975 \\
\hline $60-80 \%$ & IV & 280 & $1,976,077$ & 0.932 & 0.793 & 0.982 \\
\hline $80-100 \%$ & $\mathrm{~V}$ & 277 & $3,821,929$ & 0.946 & 0.759 & 0.982 \\
\hline Overall & & $1,367^{2}$ & $1,682,224$ & 0.911 & 0.320 & 0.998 \\
\hline
\end{tabular}

TP, and SEC; and (2) TFPC2, which is equal to TFPC1 plus AEC. To calculate the latter, we computed the share for each input on total costs, and such computations were straightforward except for $\mathrm{CO}$. To obtain the shares for cows we calculated an annual user cost per cow, which included depreciation and opportunity cost of the capital invested on the animals. Depreciation was calculated as (average heifer price - average cull cow price) divided by the useful life of a dairy cow, estimated at $3.5 \mathrm{yr}$. The average opportunity cost of capital was computed as (average heifer price + average cull cow price) divided by 2 . The heifer and cull cow prices were obtained directly from the TODOAGRO database.

Table 4 shows average TFPC1 and TFPC2 along with the various components by quintile and overall calculations. The data reveal a fair amount of variability across TFPC components and quintiles. Focusing first on TFPC1 for the entire sample, we observed that the dominant component is TP $(2.15 \%)$, followed by TEC $(0.25 \%)$ and SEC $(-0.14 \%)$, which yields an average annual rate of growth in TFP equal to $2.25 \%$. The lowest rate of growth according to TFPC1 was for quintile III (1.70\%), whereas the highest was for quintile $\mathrm{V}$ at $2.54 \%$.

The TFPC2 data for the entire sample showed a positive role for AEC of $0.32 \%$. The average annual rate of growth in TFP went up to $3.04 \%$ for quintile
I, whereas the lowest rate of growth was for quintile II $(2.33 \%)$, with an overall average of $2.57 \%$. Thus, the inclusion of AEC leads to a gap between the TFPC1 and TFPC2, with a larger effect in small farms (quintiles I and II) than large farms. In other words, AEC has an important role in productivity growth and this role is relatively larger in small farms; or, productivity growth is not only possible through positive technological progress or by improving managerial practices (positive TEC), but also by moving toward an optimal (i.e., cost minimizing) input mix.

A noteworthy implication of the relatively low TEC rate is that productivity gains through management improvements are still possible. By contrast, the relatively high rate of $\mathrm{TP}$ suggests that investments in research have had a significant role in the promotion of productivity growth. The contributions of research seem even more relevant in the current environment of growing market liberalization, where farmers in developing countries face increasing competition from their peers in other places, including rich economies where the public sector provides relatively high levels of support to agricultural research, innovation, and extension services (Blayney and Gehlhar, 2005).

Evidence from our investigation suggests that farm size does not play a significant role in the productivity growth of the dairy farms in the sample. However,

Table 4. Total factor productivity change (TFPC) decomposition by quintile in terms of milk production ${ }^{1}$

\begin{tabular}{|c|c|c|c|c|c|c|c|c|}
\hline Groups $^{2}$ & & $\begin{array}{l}\text { No. of } \\
\text { Farms }\end{array}$ & $\begin{array}{c}\text { TEC } \\
(\%)\end{array}$ & $\begin{array}{l}\mathrm{TP} \\
(\%)\end{array}$ & $\begin{array}{c}\text { SEC } \\
(\%)\end{array}$ & $\begin{array}{c}\text { TFPC1 } \\
(\%)\end{array}$ & $\begin{array}{c}\mathrm{AEC} \\
(\%)\end{array}$ & $\begin{array}{c}\text { TFPC2 } \\
(\%)\end{array}$ \\
\hline $0-20 \%$ & I & 116 & 0.15 & 2.00 & 0.15 & 2.30 & 0.75 & 3.04 \\
\hline $20-40 \%$ & II & 167 & 0.45 & 2.17 & -0.17 & 2.44 & -0.11 & 2.33 \\
\hline $40-60 \%$ & III & 182 & -0.18 & 2.04 & -0.16 & 1.70 & 0.69 & 2.39 \\
\hline $60-80 \%$ & IV & 192 & 0.45 & 2.07 & -0.21 & 2.31 & 0.14 & 2.44 \\
\hline $80-100 \%$ & $\mathrm{~V}$ & 188 & 0.32 & 2.40 & -0.18 & 2.54 & 0.27 & 2.81 \\
\hline Overall & & 845 & 0.25 & 2.15 & -0.14 & 2.25 & 0.32 & 2.57 \\
\hline
\end{tabular}

${ }^{1} \mathrm{TEC}=$ technical efficiency change; $\mathrm{TP}=$ technological progress; $\mathrm{SEC}=$ scale efficiency change; $\mathrm{TFPC} 1=$ total factor productivity change according to Nishimizu and Page (1982) equal to TEC + TP + SEC; AEC $=$ allocative efficiency change; TFPC2 $=$ total factor productivity change according to Kumbhakar and Lovell (2000) and Coelli et al. (2003) equal to TEC + TP + SEC + AEC.

${ }^{2}$ Quintiles are defined in terms of milk production. 
aggregate country-level data reveal a clear structural change in Chilean dairy production over the past $15 \mathrm{yr}$ toward fewer and larger farms. The implication of our results combined with this observed structural change is that a major driver of dairy farm growth is the search for higher income rather than lower costs of production.

In the future, it is reasonable to expect that the Chilean agricultural sector will remain competitive given the country's advantageous natural resource base, political stability, and rapidly evolving physical infrastructure. Therefore, we can envision the coexistence of a wide spectrum of farm sizes provided that other sources of revenue, perhaps from nonfarm rural activities, are available for the small-scale farmers that wish to supplement their dairy production income. Nevertheless, if the Chilean economy remains on a steady growth path, we anticipate further structural change away from smaller farms in favor of larger operations as workers are drawn to more lucrative opportunities outside of agriculture. This is even more likely in dairy farming, where the option to mechanize various facets of the production process is readily available. Larger farms, if they continue to generate healthy returns, will be in a position to absorb smaller operations to further enhance profits and this would continue to drive the shift toward fewer but bigger dairy operations.

\section{ACKNOWLEDGMENTS}

This work was partially supported by the National Fund for Science and Technology (FONDECYT, Santiago, Chile) under Grant 11110285 and the Research and Development Direction of Universidad Austral de Chile. The paper is in memory of Luis Latrille for his important contributions to the improvement of dairy farming.

\section{REFERENCES}

Acock, A. 2010. A Gentle Introduction to Stata. 3rd ed. Stata Press, College Station, TX.

Ahmad, M., and B. E. Bravo-Ureta. 1995. An econometric decomposition of dairy output growth. Am. J. Agric. Econ. 77:914-921. http://dx.doi.org/10.2307/1243814.

Ahmad, M., and B. E. Bravo-Ureta. 1996. Technical efficiency measures for dairy farms using panel data: A comparison of alternative model specifications. J. Prod. Anal. 7:399-415. http://dx.doi. org/10.1007/BF00162049.

Bailey, D., B. Biswas, S. C. Kumbhakar, and K. Schulthies. 1989. An analysis of technical, allocative, and scale inefficiency: The case of Ecuadorian dairy farms. West. J. Agric. Econ. 14:30-37. http:// www.jstor.org/stable/40988006.

Battese, G. E., and T. J. Coelli. 1988. Prediction of firm-level technical efficiencies with a generalized frontier production function and panel data. J. Econom. 38:387-399. http://dx.doi.org/10.1016/03044076(88)90053-X.

Bauer, P. W. 1990. Decomposing TFP growth in the presence of cost inefficiency, nonconstant returns to scale, and technological progress. J. Prod. Anal. 1:287-299. http://dx.doi.org/10.1007/ BF00160047.

Berry, A. R., and W. R. Cline. 1979. Agrarian Structure and Productivity in Developing Countries. The Johns Hopkins University Press, Baltimore, MD.

Blayney, D. P., and M. J. Gehlhar. 2005. U.S. dairy at a new crossroads in a global setting. Amber Waves 3:1-6. http://EconPapers. repec.org/RePEc:ags:uersaw:127367.

Bojnec, S., and L. Latruffe. 2013. Farm size, agricultural subsidies and farm performance in Slovenia. Land Use Policy 32:207-217. http://dx.doi.org/10.1016/j.landusepol.2012.09.016.

Bravo-Ureta, B. E., and L. Rieger. 1991. Dairy farm efficiency measurement using stochastic frontiers and neoclassical duality. Am. J. Agric. Econ. 73:421-428. http://dx.doi.org/10.2307/1242726.

Bravo-Ureta, B. E., D. Solís, V. H. Moreira, J. F. Maripani, A. Thiam, and T. E. Rivas. 2007. Technical efficiency in farming: A meta-regression analysis. J. Prod. Anal. 27:57-72. http://dx.doi. org/10.1007/s11123-006-0025-3.

Brümmer, B., T. Glauben, and G. J. Thijssen. 2002. Decomposition of productivity growth using distance functions: The case of dairy farms in three European countries. Am. J. Agric. Econ. 84:628644. http://dx.doi.org/10.1111/1467-8276.00324.

Cabrera, V. E., D. Solís, and J. d. Corral. 2010. Determinants of technical efficiency among dairy farms in Wisconsin. J. Dairy Sci. 93:387-393. http://dx.doi.org/10.3168/jds.2009-2307.

Carletto, C., S. Savastano, and A. Zezza. 2013. Fact or artifact: The impact of measurement errors on the farm size-productivity relationship. J. Dev. Econ. 103:254-261. http://dx.doi.org/10.1016/j. jdeveco.2013.03.004.

Chen, P.-C., M.-M. Yu, C.-C. Chang, and S.-H. Hsu. 2008. Total factor productivity growth in china's agricultural sector. China Econ. Rev. 19:580-593. http://dx.doi.org/10.1016/j.chieco.2008.07.001.

Coelli, T. 1996. A guide to frontier version 4.1: A computer program for stochastic frontier production and cost function estimation. 4.1 ed. CEPA Working Paper 96/7, Department of Econometrics, University of New England, Armidale NSW Australia, Australia.

Coelli, T. J., A. Estache, S. Perelman, and L. Trujillo. 2003. A Primer on Efficiency Measurement for Utilities and Transport Regulators. The World Bank, Washington, DC.

Coelli, T. J., D. S. P. Rao, C. J. O'Donnell, and G. E. Battese. 2005. An Introduction to Efficiency and Productivity Analysis. 2nd ed. Springer, New York, NY.

Dawson, P. J., and B. White. 1990. The post-quota performance of dairy farms in England and Wales. Appl. Econ. 22:1399-1406. http://dx.doi.org/10.1080/00036849000000110.

del Corral, J., J. A. Perez, and D. Roibas. 2011. The impact of land fragmentation on milk production. J. Dairy Sci. 94:517-525. http://dx.doi.org/10.3168/jds.2010-3377.

Fuglie, K. O. 2010. Sources of growth in indonesian agriculture. J. Prod. Anal. 33:225-240. http://dx.doi.org/10.1007/s11123-0090150-x.

Fundación Chile. 2007. Manual de Metodologías. Ministerio de Agricultura, Gobierno de Chile, Vitacura, Santiago, Chile.

Hansson, H., and B. Öhlmér. 2008. The effect of operational managerial practices on economic, technical and allocative efficiency at Swedish dairy farms. Livest. Sci. 118:34-43. http://dx.doi. org/10.1016/j.livsci.2008.01.013.

Hazell, P., C. Poulton, S. Wiggins, and A. Dorward. 2007. The future of small farms for poverty reduction and growth. 2020 Discussion Paper 42. International Food Policy Research Institute. Accessed Mar. 1, 2009. http://www.ifpri.org/publication/future-smallfarms-poverty-reduction-and-growth.

Jondrow, J., C. A. K. Lovell, I. S. Materov, and P. Schmidt. 1982. On the estimation of technical inefficiency in the stochastic frontier production function model. J. Econom. 19:233-238. http://dx.doi. org/10.1016/0304-4076(82)90004-5.

Kellermann, M., and K. Salhofer. 2014. Dairy farming on permanent grassland: Can it keep up? J. Dairy Sci. 97:6196-6210. http:// dx.doi.org/10.3168/jds.2013-7825.

Kopp, R. J., and W. E. Diewert. 1982. The decomposition of frontier cost function deviations into measures of technical and allocative 
efficiency. J. Econom. 19:319-331. http://dx.doi.org/10.1016/03044076(82)90008-2.

Kumbhakar, S. C., S. Ghosh, and J. T. McGuckin. 1991. A generalized production frontier approach for estimating determinants of inefficiency in U.S. dairy farms. J. Bus. Econ. Stat. 9:279-286. http:// dx.doi.org/10.1080/07350015.1991.10509853.

Kumbhakar, S. C., G. Lien, O. Flaten, and R. Tveteras. 2008. Impacts of Norwegian milk quotas on output growth: A modified distance function approach. J. Agric. Econ. 59:350-369. http:// dx.doi.org/10.1111/j.1477-9552.2008.00154.x.

Kumbhakar, S. C., and C. A. K. Lovell. 2000. Stochastic Frontier Analysis. Cambridge University Press, New York, NY.

Lachaal, L. 1994. Subsidies, endogenous technical efficiency and the measurement of productivity growth. J. Agric. Appl. Econ. $26: 299-310$.

Lawson, L. G., J. F. Agger, M. Lund, and T. J. Coelli. 2004a. Lameness, metabolic, and digestive disorders and technical efficiency in Danish dairy herds: A stochastic frontier production function approach. Livest. Prod. Sci. 91:157-172. http://dx.doi.org/10.1016/j. livprodsci.2004.07.016.

Lawson, L. G., J. Brunn, T. J. Coelli, J. F. Agger, and M. Lund. 2004b. Relationships of efficiency to reproductive disorders in Danish milk production: A stochastic frontier analysis. J. Dairy Sci. 87:212-224. http://dx.doi.org/10.3168/jds.S0022-0302(04)73160-

Maietta, O. W. 2000. The decomposition of cost inefficiency into technical and allocative components with panel data of Italian dairy farms. Eur. Rev. Agric. Econ. 27:473-495. http://dx.doi. org/10.1093/erae/27.4.473.

Martin, J. P., and J. M. Page Jr. 1983. The impact of subsidies on xefficiency in ldc industry: Theory and an empirical test. Rev. Econ. Stat. 65:608-617. http://dx.doi.org/10.2307/1935929.

Moreira, V. H., and B. E. Bravo-Ureta. 2009. A study of dairy farm technical efficiency using meta-regression: An international perspective. Chilean J. Agric. Res. 69:214-223. http://dx.doi org/10.4067/S0718-58392009000200011.

Morrison, C. 1999. Cost Structure and the Measurement of Economic Performance. Productivity Growth, Utilization, Cost Economies, and Related Performance Indicators. Kluwer Academic Publisher, Norwell, MA.

Mosheim, R., and C. A. K. Lovell. 2009. Scale economies and inefficiency of U.S. dairy farms. Am. J. Agric. Econ. 91:777-794. http://dx.doi.org/10.1111/j.1467-8276.2009.01269.x.

Newman, C., and A. Matthews. 2007. Evaluating the productivity performance of agricultural enterprises in Ireland using a multiple output distance function approach. J. Agric. Econ. 58:128-151. http://dx.doi.org/10.1111/j.1477-9552.2007.00084.x.

Nishimizu, M., and J. M. Page Jr. 1982. Total factor productivity growth, technological progress and technical efficiency change: Di- mensions of productivity change in Yugoslavia, 1965-78. Econ. J 92:920-936. http://dx.doi.org/10.2307/2232675.

Piesse, J., C. Thirtle, and J. Turk. 1996. Efficiency and ownership in Slovene dairying: A comparison of econometric and programming techniques. J. Comp. Econ. 22:1-22. http://dx.doi.org/10.1006/ jcec.1996.0001.

Qi, L., B. E. Bravo-Ureta, and V. E. Cabrera. 2015. From cold to hot: Climatic effects and productivity in Wisconsin dairy farms. J. Dairy Sci. 98:8664-8677. http://dx.doi.org/10.3168/jds.2015-9536.

Rao, D. S. P., and T. J. Coelli. 2004. Catch-up and convergence in global agricultural productivity. Indian Econ. Rev. 39:123-148. http://www.jstor.org/stable/29793808.

Reinhard, S., C. A. K. Lovell, and G. J. Thijssen. 1999. Econometric estimation of technical and environmental efficiency: An application to Dutch dairy farms. Am. J. Agric. Econ. 81:44-60. http:// dx.doi.org/10.2307/1244449.

Richards, T. J. 1995. Supply management and productivity growth in Alberta dairy. Can. J. Agric. Econ. 43:421-434. http://dx.doi org/10.1111/j.1744-7976.1995.tb00132.x.

Ruttan, V. W. 2002. Productivity growth in world agriculture: Sources and constraints. J. Econ. Perspect. 16:161-184. http://dx.doi org $/ 10.1257 / 089533002320951028$

Solow, R. M. 1957. Technical change and the aggregate production function. Rev. Econ. Stat. 39:312-320. http://dx.doi org $/ 10.2307 / 1926047$.

Tauer, L. W. 1993. Short-run and long-run efficiencies of New York dairy farms. Agric. Res. Econ. Rev. 22:1-9. http://purl.umn. $\mathrm{edu} / 31637$.

Tauer, L. W. 1998. Productivity of New York dairy farms measured by nonparametric malmquist indices. J. Agric. Econ. 49:234-249. http://dx.doi.org/10.1111/j.1477-9552.1998.tb01266.x.

Thirtle, C., L. Lin, and J. Piesse. 2003. The impact of research-led agricultural productivity growth on poverty reduction in Africa, Asia and Latin America. World Dev. 31:1959-1975. http://dx.doi. org/10.1016/j.worlddev.2003.07.001

United Nations (UN). 2015. Sustainable Developments Goals. United Nations, New York, NY. Accessed Apr. 1, 2016. http://www un.org/sustainabledevelopment/sustainable-development-goals/.

van der Voort, M., J. V. Meensel, L. Lauwers, J. Vercruysse, G. V. Huylenbroeck, and J. Charlier. 2014. A stochastic frontier approach to study the relationship between gastrointestinal nematode infections and technical efficiency of dairy farms. J. Dairy Sci 97:3498-3508. http://dx.doi.org/10.3168/jds.2013-7444

World Bank. 2003. World Development Report 2003: Sustainable development in a dynamic world: Transforming institutions, growth, and quality of life. Accessed Dec. 10, 2006. https:// openknowledge.worldbank.org/handle/10986/5985.

World Bank. 2008. World Development Report 2008: Agriculture for development. World Bank, Washington, DC. 